\title{
PENGARUH TERAPI OKUPASI AKTIVITAS WAKTU LUANG TERHADAP PERUBAHAN HALUSINASI PENDENGARAN PADA PASIEN JIWA
}

\author{
Heru Wahyudi ${ }^{1}$, Cucuk Suwandi ${ }^{1}$, Eike Widya Agustyani' ${ }^{2}$, \\ , ${ }^{1}$ Dosen STIKes Satria Bhakti Nganjuk \\ ${ }^{2}$ Mahasiswa STIKes Satria Bhakti Nganjuk \\ Email : e.agustyani@gmail.com
}

\begin{abstract}
Introduction: Hearing hallucinations that occur continuously and are not immediately treated can potentially lead to maladaptive actions. Occupational therapy activities at leisure can distract clients from auditory hallucinations, so they don't get worse.The purpose of this study was to determine the effect of occupational therapy on leisure activities on changes in auditory hallucinations in mental patients at the Rejoso Health Center in Nganjuk Regency. Methods: The design of this study was to pre-experiment with the One Group Pre-Post Test Design approach. The study was conducted on $12^{\text {th }}-18^{\text {th }}$ February 2019 at Rejoso Health Center. The population was all auditory hallucinatory patients who were treated at the Rejoso Health Center in Nganjuk Regency, as many as 25 people. Samples were taken with the technique The sampling technique used in this study was Accidental and obtained a sample of 20 people. Independent variable is leisure time occupational therapy and the dependent variable is auditory hallucinatory changes. The instruments are standard operational procedures and observation sheets. Data was analyzed using paired sample T test with $\alpha=$ 0.05. Result: The results of this study indicate that out of 20 mental patient respondents before being given occupational therapy for leisure time, it was found that the auditory hallucination scores of 5 with 6 person $(30 \%)$. Of the 20 psychiatric patient respondents after being given free occupational therapy, it was found to have an auditory hallucination score of 1 with 12 person (60\%). The results of the paired T test produce p-value $=0,000 \alpha \alpha(0,05)$, so that $\mathrm{H} 0$ is rejected or $\mathrm{Ha}$ is accepted, meaning that there is the influence of occupational therapy on leisure activities on auditory hallucinatory changes in mental patients at the Rejoso Health Center. Conclusion: Through leisure time occupational therapy, auditory hallucinatory patients are given a pleasant and beneficial activity, so they concentrate on their activities and there is no chance to daydream, so that sensory responses without external stimuli of auditory hallucinations can be minimized. It is recommended for Rejoso Community Health Center to develop occupational therapy strategies for free time by adding a variety of activities to patients.
\end{abstract}

Keywords : Leisure Occupational Therapy, Auditory Hallucinations, Mental Disorder Patients.

\section{Pendahuluan}

$$
\text { Halusinasi merupakan gejala }
$$

positif dari skizofrenia dan sering juga terjadi pada klien maniak depresif dan delirium (Muhith, 2015).Tanda-tanda umum halusinasi adalah berbicara, tersenyum dan tertawa sendiri, menarik diri dari orang lain, tidak dapat membedakan yang nyata dan tidak nyata
(Maramis, 2010).Jenis halusinasi yang paling sering ditemukan adalah halusinasi pendengaran (auditory hallucination).Semakin tinggi intensitas halusinasi pendengaran, maka semakin besar pengaruhnya pada sikap dan perilaku pasien yang berpotensi menjurus kepada tindakan maladaptif (Stuart dan Sundeen, 2008).Karena itu, diperlukan aktivitas 
positif pada waktu luang untuk mengalihkan perhatian klien dari halusinasi yang dialami, misalnya olahraga, bersih-bersih, dan membuat kerajinan tangan. Berdasarkan studi pendahuluan berupa wawancara dengan Kepala Puskesmas Rejoso pada tanggal 30 Agustus 2018 tentang perkembangan 5 pasien halusinasi pendengaran yang baru masuk di Puskesmas Rejoso Kabupaten Nganjuk, diperoleh informasi sebanyak 4 pasien $(80 \%)$ mengalami penurunan frekuensi halusinasi setelah rutin diajak olahraga, bernyanyi bersama, dan meronce manik-manik. Namun terdapat 1 pasien yang tidak kooperatif dan tidak mau melakukan aktivitas di waktu luang.Kondisi pasien tersebut tidak mengalami penurunan halusinasi pendengaran.

Masalah gangguankesehatan jiwa di seluruh dunia sudah menjadi masalah yang sangatserius.Menurut WHOdiperkirakan sekitar 450 juta jiwa di seluruh dunia menderita gangguan kesehatan jiwa atau paling tidak, ada satu dari empat orang di duniayang mengalami gangguan kesehatan jiwa (Safitri, 2011).Berdasarkan SurveiRiset Kesehatan Dasar (Riskesdas) tahun 2013 (dalam Tempo, 2017) dikombinasi dengan data rutin dari Pusdatin dengan waktu yang disesuaikansecara nasional terdapat $0,17 \%$ penduduk Indonesia mengalami gangguanjiwa berat (psikosis) atau sekitar 400 ribu jiwa. Berdasarkan data Dinsos Jatim, jumlah Orang Dengan Gangguan Jiwa (ODGJ) di Jatim pada tahun 2016 mencapai 2.369 orang. Jumlah tersebut naik sebesar 750 orang dibandingkan tahun 2015 lalu sebesar 1.619 orang penderita (Beritajatim, 2017).Data RSJ Menur menyatakan bahwa pada tahun 2016 jumlah pasien ODGJ yang dilaporkan sebanyak 761 kasus. Di Kabupaten Nganjuk, jumlah pasien ODGJ yang dirawat di Puskesmas Rejoso pada Bulan Agustus 2018 tercatat jumlah total pasien gangguan jiwa yang dirawat sebanyak 52 pasien. Dari jumlah tersebut, pasien yang terdiagnosa mengalami halusinasi pendengaran sebanyak 25 orang (49\%).

\section{Metode}

Desain penelitian ini adalah pra eksperimen dengan pendekatan One GroupPre-Post Test Design yaitu menguji keberhasilan suatu perlakuan dengan cara membandingkan kondisi sebelum (pre) dan sesudah (post) diberi perlakuan, yang dilaksanakan pada tanggal 12-18 Februari 2019 berlokasi di Puskesmas Rejoso Kabuaten Nganjuk. Populasi penelitian ini adalah seluruh pasien halusinasi pendengaran yang dirawat di Puskesmas 
Rejoso Kabupaten Nganjuk, rata-rata per bulan sebanyak 25 orang. Teknik sampling Accidental Samplingsampel 20 responden. Variable independent terapi okupasi waktu luang, variable dependent perubahan halusinasi pendengaran.Pengumpulan data menggunakan SOP dan lembar observasi.Adapun dalam penelitian ini dilakukan dengan teknik terapi yaitu dengan diberikan terapi aktivitas waktu luang dengan memberikan kegiatan berupa meronce manik-manik pada pasien perempuan dan membuat kemoceng pada pasien laki-laki.Terapi ini diberikan selama 7 hari, lama waktu pemberian terapi adalah 45 menit diberikan pada saat waktu luang pasien yaitu pukul 15.0015.45. Analisa data statistic dilakukan dengan uji T Berpasangan dengan $\alpha 0,05$.

\section{Hasil :}

Pengaruh Terapi Okupasi Waktu Luang terhadap Perubahan Halusinasi Pendengaran Pada Pasien Jiwa di Puskesmas Rejoso Kabupaten Nganjuk.

Tabel 1 Pengaruh Terapi Okupasi Waktu Luangterhadap Perubahan Halusinasi Pendengaran pada Pasien Jiwa di Puskesmas RejosoKabupaten Nganjuk, tanggal 12-18Februari 2019.

\begin{tabular}{|c|c|c|c|c|c|c|c|c|c|c|}
\hline \multirow{3}{*}{$\begin{array}{c}\text { Skor } \\
\text { Halusin } \\
\text { asi } \\
\text { Pendeng } \\
\text { aran } \\
\text { Pretest }\end{array}$} & \multicolumn{8}{|c|}{$\begin{array}{c}\text { Skor Halusinasi Pendengaran } \\
\text { Posttest }\end{array}$} & \multirow{2}{*}{\multicolumn{2}{|c|}{ Total }} \\
\hline & \multicolumn{2}{|c|}{1} & \multicolumn{2}{|c|}{2} & \multicolumn{2}{|c|}{3} & \multicolumn{2}{|c|}{7} & & \\
\hline & $f$ & $\%$ & $f$ & $\%$ & $F$ & $\%$ & $f$ & $\%$ & $f$ & $\%$ \\
\hline 2 & 1 & 5 & 0 & 0 & 0 & 0 & 0 & 0 & 1 & 5 \\
\hline 3 & 2 & 10 & 0 & 0 & 0 & 0 & 0 & 0 & 2 & 10 \\
\hline 4 & 2 & 10 & 1 & 5 & 0 & 0 & 0 & 0 & 3 & 15 \\
\hline 5 & 5 & 25 & 1 & 5 & 0 & 0 & 0 & 0 & 6 & 30 \\
\hline 6 & 0 & 0 & 1 & 5 & 0 & 0 & 0 & 0 & 1 & 5 \\
\hline 7 & 1 & 5 & 0 & 0 & 1 & 5 & 0 & 0 & 2 & 10 \\
\hline 9 & 1 & 5 & 0 & 0 & 0 & 0 & 1 & 5 & 2 & 10 \\
\hline 10 & 0 & 0 & 1 & 5 & 1 & 5 & 0 & 0 & 2 & 10 \\
\hline 11 & 0 & 0 & 0 & 0 & 1 & 5 & 0 & 0 & 1 & 5 \\
\hline Total & 12 & 60 & 4 & 20 & 3 & 15 & 1 & 5 & 20 & 100 \\
\hline & & U & & & & & & & & \\
\hline
\end{tabular}

Berdasarkan tabel 1 menunjukkan bahwa dari 20responden pasien jiwa di Puskesmas Rejoso, sebagian kecil sebelum diberi terapi okupasi waktu luang, diketahui memiliki skor halusinasi pendengaran sebesar 5 dengan jumlah 6 orang $(30 \%)$, kemudian sesudahdiberi terapi okupasi waktu luang, diketahui memiliki skor halusinasi pendengaran sebesar 1 dengan jumlah 12 orang(60\%).

Hasil pengujian hipotesis penelitian dengan menggunakan Uji T Berpasangan dan bantuan program SPSS for Windowsmenghasilkan nilai $p$-value $=$ $0,000 \leq \alpha(0,05)$, sehingga $\mathrm{H} 0$ ditolak atau Ha diterima. Dengan demikian berarti ada pengaruh terapi okupasi aktivitas waktu luang terhadap perubahan halusinasi pendengaran pada pasien jiwa di Puskesmas Rejoso Kabupaten Nganjuk.

\section{Pembahasan}




\section{Halusinasi Pendengaran Sebelum}

\section{Terapi Okupasi Waktu Luang}

Hasil penelitian pada tabel 4.1 menunjukkan bahwa dari 20 respondenpasien jiwa di Puskesmas Rejoso Kabupaten Nganjuk, sebelum diberi terapi okupasi, diketahui hampir setengahnya memiliki skor halusinasi pendengaran sebesar 5 dengan jumlah 6 orang(30\%).Selanjutnya hasil tabulasi silang dengan data umum menunjukkan bahwa adanya hubungan perubahanhalusinasi pendengaran sebelum diberi terapi okupasi waktu luang dengan lama perawatan $(p$-value $=0,032)$ dan riwayat perawatan sebelumnya $(p$-value $=$ $0,010)$.

Stuart dan

Sundeen (2008)menyatakan bahwa pasien jiwa memerlukan perawatan khusus agar tidak semakin bertambah parah.Semakin parah kondisi gangguan jiwa pada pasien, maka mungkin semakin lama perawatan kejiwaan yang diperlukan.Kusmawati dan Hartono (2010) menyatakan bahwa riwayat perawatan dapat memberikan gambaran kondisi kejiwaan pasien.Umumnya pasien jiwa yang tidak pernah dirawat memiliki tingkat gangguan jiwa yang parah dan perlu waktu lama penyembuhannya.

Uraian di atas menunjukkan bahwa riwayat perawatan sebelumnya menunjukkan bahwa klien memiliki gangguan halusinasi pendengaran yang memerlukan perawatan segera, sehingga klien harus menjalani lama perawatan cukup lama serta kambuh berkali-kali setelah dirawat di instansi pelayanan kesehatan jiwa. Lama perawatan yang panjang, namun belum membuahkan hasil yang diharapkan, sehingga perlu untuk segera dievaluasi lebih lanjut agar dapat dilakukan perbaikan.Selain itu dukungan obat farmakologi sangat diperlukan agar kondisi pasien tidak mudah kambuh.

\section{Halusinasi Pendengaran Sesudah}

\section{Terapi Okupasi Waktu Luang}

Berdasarkan tabel 4.2, dari 20 respondenpasien jiwa di Puskesmas Rejoso Kabupaten Nganjuk, sesudah diberi terapi okupasi, diketahui sebagian besar memiliki skor halusinasi pendengaran $\begin{array}{llll}\text { sebesar } 1 \text { dengan jumlah } 12 & 12\end{array}$ orang $(60 \%)$.Selanjutnya hasil data statistik dengan data umum tidak ada satupun yang menunjukkan hubungan yang signifikan dengan halusinasi pendengaran sesudah diberi terapi okupasi waktu luang pada pasien jiwa di Puskesmas Rejoso.

Stuart dan Sundeen (2008) menyatakan bahwa faktor utama yang dapat menurunkan tingkat halusinasi pendengaran adalah melalui upaya terapi dan farmakologis.Sedangkan Yosep (2011) menyatakan bahwa halusinasi 
disebabkan karena ketidakmampuan pasien menghadapi stressor dan tidak mampu mengendalikan halusinasi.Namun penyebab tunggal secara jelas sampai saat ini belum ditemukan, karena adanya dugaan penyebab lain dari faktor genetik, virus, auto-antibody dan malnutrisi.

Berdasarkan uraian di atas, dapat dinyatakan bahwa halusinasi pendengaran kecil kemungkinan bisa sembuh dengan sendirinya.Karena itu perlu dilakukan perawatan yang sesuai dan terstruktur dari tenaga kesehatan jiwa.Sedangkan faktorfaktor demografis secara umum kurang berpengaruh pada kondisi pasien halusinasi.Karena itu dapat dipahami mengapa dalam penelitian ini tidak ditemukan hubungan antara data demografis dengan frekuensi halusinasi pendengaran yang dialami pasien.Halusinasi pendengaran dapat menyerang siapa saja, baik laki-laki maupun perempuan, tua maupun muda, dan tidak dipengaruhi oleh faktor-faktor demografis.

3. Pengaruh Terapi Okupasi Waktu Luang terhadap Perubahan HalusinasiPendengaran

Berdasarkan tabel 4.3 dari 20responden pasien jiwa di Puskesmas Rejoso, sebelum diberi terapi okupasi waktu luang memiliki skor halusinasi sebesar 5.Kemudian sesudahdiberi terapi okupasi waktu luang, skor halusinasi pendengaran sebesar 1.Dengan demikian terdapat perubahan halusinasi pendengaran pada pasien jiwa sebesar 4. Hasil uji $\mathrm{T}$ Berpasangan menghasilkan nilai $p$-value $=$ $0,000 \leq \alpha(0,05)$, sehingga H0 ditolak atau Ha diterima, berarti ada pengaruh terapi okupasi aktivitas waktu luang terhadap perubahan halusinasi pendengaran pada pasien jiwa di Puskesmas Rejoso Kabupaten Nganjuk.

Menurut Stuart dan Sundeen (2008), semakin tinggi intensitas halusinasi pendengaran, semakin berpotensi menjurus kepada tindakan maladaptif. Karena itu, diperlukan aktivitas positif untuk mengalihkan perhatian klien dari halusinasi yang dialami.Djunaedi dan Yitnamurti (2008) menyatakan bahwa salah satu terapi yang direkomendasikan adalah dengan terapi okupasi, yaitu psikoterapi suportif untuk kesembuhan pasien melalui aktivitas yang disenangi oleh pasien. Aktivitas tersebut dapat dilakukan pada waktu luang dalam bentuk olahraga dan kegiatan yang lainyang menyenangkan.Sedangkan menurut Prabowo (2017) terapi okupasi aktivitas mencakup segala macam aktivitas yang dapat menyibukkan seseorang secara produktif. Terapi okupasi aktivitas berfungsi untuk menciptakan kondisi tertentu, sehingga pasien dapat 
mengembangkan kemampuannya untuk dapat berhubungan dengan orang lain dan masyarakat sekitarnya. Creek (2010) menambahkan bahwa aktivitas waktu luang membantu mencegah terjadinya stimuli panca indera tanpa adanya rangsangan dari luar, sehingga frekuensi halusinasi dapat ditekan.

Hasil penelitian ini mendukung hasil penelitian Wijayanti (2011) yang menyatakanbahwa ada pengaruh yang sangat signifikan pemberian terapi okupasi aktivitas waktu luang terhadap perubahan gejala halusinasi pendengaran yang dialami oleh pasien skizofrenia dengan $p$ value $=0,000$. Demikain pula hasil penelitian Candra (2014) menyatakan bahwa ada pengaruh yang sangat signifikan pemberian terapi okupasi aktivitas terhadap perubahan gejala halusinasi pada pasien skizofrenia dengan $p$-value $=0,000$. Hasil penelitian ini lainnya adalah Elisia (2014) yang membuktikan bahwa ada pengaruh terapi okupasi terhadap kemampuan berinteraksi pada pasien isolasi sosial. Terapi okupasi direkomendasikan sebagai terapi keperawatan dalam merawat pasien dengan isolasi sosial dengan penurunan kemampuan interaksi sosial dengan $p$ value $=0,000$.

Berdasarkan uraian di atas, maka peneliti berpendapat bahwa pemberian terapi okupasi waktu luang pada pasien jiwa dengan halusinasi pendengaran di Puskesmas Rejoso dalam penelitian ini telah berhasil menurunkan tingkat halusinasi pendengaran secara bermakna.Rata-rata pasien awalnya (pretest) memiliki tingkat halusinasi cukup tinggi (di atas skor 5), kemudian diberi terapi okupasi waktu luang berupa kegiatan meronce dan membuat kemoceng. Sesudah dilakukan terapi okupasi waktu luang tersebut selama 7 hari, maka ditemukan adanya penurunan rata-rata tingkat halusinasi pendengaran (post-test) menjadi sebesar 1,8. Melalui terapi okupasi waktu luang, pasien halusinasi pendengaran diberi kesibukan yang menyenangkan dan bermanfaat, sehingga mereka berkonsentrasi pada aktivitasnya itu dan tidak ada kesempatan untuk melamun, sehingga respon inderawi tanpa rangsangan dari luar berupa halusinasi pendengaran dapat diminimalkan, bahkan hampir tidak terjadi sama sekali.

\section{Kesimpulan}

Hasil Penelitian diatas menunjukkan bahwa ada pengaruh terapi okupasi waktu luang terhadap perubahan halusinasi pada pasien halusinasi pendengaran di Puskesmas Rejoso Kabupaten Nganjuk.Pemberian terapi okupasi waktu luang yaitu dengan 
memberikan kegiatan kepada pasien halusinasi pendengaran yaitu meronce manik-manik untuk pasien perempuan dan membuat kemoceng untuk pasien laki-laki dengan durasi terapi 45 menit/hari dilakukan selama 7 hari.Diharapkan hasil penelitian ini dapat dikembangkan oleh peneliti selanjutnyadengan mengambil populasi yang berbeda.

\section{Daftar Pustaka}

Arikunto, S. (2010). Prosedur Penelitian Suatu Pendekatan Praktik. Jakarta: Rineka Cipta.

Bilqis.(2012). Lebih Dekat dengan Anak Tuna Daksa. Yogyakarta: Familia.

Beritajatim.com. (2017).Penderita Gangguan Jiwa di Jatim Naik Drastis. Sumber: http://m.beritajatim.com/pendidikan kesehatan/286829/. Diunduh tanggal 2 Desember 2018. Jam 12.14 WIB.

Creek, (2010).Comprehensive Texbook of Psychiatry.Seventh Edition. New York: Williams \& Wilkins.

Dermawan, D. dan Rusdi. (2013). Keperawatan Jiwa: Konsep dan Kerangka Kerja Asuhan Keperawatan Jiwa. Yogyakarta: Gosyen Publishing.

Direja, S. H. A. (2011). Buku Ajar Asuhan Keperawatan Jiwa.Yogyakarta: Nuha Medika.

Djunaedi \& Yitnarmuti.(2008). Psikoterapi Gangguan Jiwa. Jakarta: PT. Buana Ilmu Populer.

Efendi, F. (2009).Keperawatan Kesehatan Komunitas: Teori dan Praktek dalam Keperawatan. Jilid 1. Jakarta: Salemba Medika

Fathurahman, R. (2017). Penerapan Terapi Okupasi pada Klien Skizofrenia dengan Gangguan Konsep Diri: Harga Diri Rendah Kronik di Wilayah Puskesmas Gombong II. Gombong: Prodi D-III Keperawatan Sekolah Tinggi Ilmu Kesehatan Muhammadiyah Gombong.

Hidayat, A. A. (2009). Metode Penelitian Kebidanan dan Teknik Analisis Data. Surabaya: Penerbit Salemba.

Kamal, S. (2010).Beberapa Jenis Penyakit Jiwa. Sumber: https://nuepoel. wordpress.comDiunduh tanggal 12 September 2018. Jam 13.18 WIB.

Kartono dan Kartini.(2009). Psikologi Abnormal. Bandung: CV. Mandar Maju.

Kristiadi, Y. (2015) Pengaruh Aktivitas Terjadwal terhadap Terjadinya Halusinasi Di RSJ Dr. Amino Gondohutomo Provinsi Jawa Tengah.Jurnal Ilmu Keperawatan dan Kebidanan (JIKK).

Kusumawati, F \& Hartono, Y. (2010).Buku Ajar Keperawatan Jiwa. Jakarta: Salemba Medika.

Lestari, W. (2013).Pengaruh Terapi Aktivitas Kelompok (TAK) Stimulasi Sensori Terhadap Kemampuan Kerjasama pada Pasien Dengan Masalah Isolasi Sosial. Pekanbaru: Program Studi Ilmu Keperawatan Universitas Riau.

Maramis, W. F. (2010). CatatanIlmu Kedokteran Jiwa. Surabaya: Airlangga University Press.

Muhith, A. (2015). Pendidikan Keperawatan Jiwa: Teori dan Aplikasi. Yogyakarta: Andi. 
Nasir, A. dan Muhith, A. (2011).Dasar Dasar Keperawatan Jiwa: Pengantar dan Teori. Jakarta: Salemba Medika.

Notoatmodjo, S. (2010).Metodologi Penelitian Kesehatan. Jakarta: Rineka.

Nursalam. (2016). Metodologi Penelitian Ilmu Keperawatan: Pendekatan Praktis. Jakarta: Salemba Medika.

PPNI.2017. Standar Diagnosis Keperawatan Indonesia: Definisi dan Indikator Diagnostik. Jakarta: Dewan Pengurus PPNI.

Prabowo, E. (2014). Buku Ajar Keperawatan Jiwa. Yogyakarta: Nuha Medika.

Safitri, D. (2011). Bukan Gila Tetapi Menderita Sakit Jiwa.Sumber: http://www.bbc.com/indonesia/lapor an_khusus/2011/10/111004_mental1 \#. Diunduh tanggal 2 Desember 2018. Jam 13.15 WIB.

Stuart, G. W. \& Sundeen. (2008). Buku Saku Keperawatan Jiwa (edisi 3), alih bahasa: Achir Yani, editor: Yasmin Asih. Jakarta: EGC.

Sugiyono. (2009). Metode Penelitian Kuantitatif, Kualitatif dan $R \& D$, Bandung: Alfabeta.
Sutejo. (2017). Keperawatan Jiwa: Konsep dan Praktik Asuhan Keperawatan Kesehatan Jiwa, Gangguan Jiwa dan Psikososial. Yogyakarta: Pustaka Baru Press.

Suzana, M. (2016).Referat Terapi Okupasi pada Pasien Skizofrenia. Bengkulu: FKIK Univesitas Bengkulu.

Tempo.co.(2017). Jumlah Penderita Depresi Meningkat dari Tahun ke Tahun. Sumber: https://gaya.tempo.co/read/876674/ju mlah-penderita-depresi-meningkatdari-tahun-ke-tahun. Diunduh tanggal 2 Desember 2018. Jam 12.11 WIB.

Wahyuni S.E., Keliat B.A., Susanti H. \& Yusron.2011.Penurunan Halusinasi pada Klien Jiwa Melalui Cognitive Behavior Theraphy.Jurnal Keperawatan Indonesia Vol. 14 No. 3.

Wijayanti, I.M.; Candra, I. W.; Ruspawan, I. D. M. (2011).Terapi Okupasi Aktivitas Waktu Luang terhadap Perubahan Gejala Halusinasi Pendengaran pada Pasien Skizofrenia.

Yosep, I. (2011). Keperawatan Jiwa. Bandung: Refika Aditama. 